\title{
Deslocamentos na percepção do Outro colonial desde a arte contemporânea.
}

\author{
LAURA RIBERO RUEDA \\ GABRIEL DE SOUZA \\ AMANDA BECKER
}

Laura Ribero Rueda é pesquisadora e professora da Universidade Feevale, RS. Doutora em Artes Visuais pela Universitat de Barcelona, Espanha (2013) e Bacharel em Artes Visuais, pela Universidad Tadeo Lozano, Bogotá, Colômbia (2000). Coordena o projeto de pesquisa 'Território nômade: migrações, transições e deslocamentos na fotografia contemporânea', na Universidade Feevale, onde reflete sobre os deslocamentos migratórios a partir das Artes Visuais e a Fotografia. Atualmente é pesquisadora convidada na Universidade de Murcia, Espanha.

Lattes:http://lattes.cnpq.br/9274197281064435

Orcid: https://orcid.org/0000-0001-5675-7721

Gabriel de Souza é graduado em História pela Universidade Feevale. Atualmente está cursando Especialização em Libras e Educação Especial, é bolsista de aperfeiçoamento científico no projeto de pesquisa "Território Nômade: migrações, transições e deslocamentos na fotografia contemporânea". Atua como Tradutor-Intérprete de Libras na Universidade Luterana do Brasil (ULBRA) e como auxiliar de biblioteca na rede privada de ensino. Tem interesse pelas relações entre História e Cultura.

Lattes: http://lattes.cnpq.br/6305201811486623

Orcid: https://orcid.org/0000-0002-2203-3351

Amanda Becker é graduada Bacharel em Artes Visuais pela Universidade Feevale (2017). Mestranda do Programa de Pós-graduação em Processos e Manifestações Culturais, na mesma Universidade, onde também é bolsista no projeto de pesquisa "O processo de criação de conteúdo nos setores criativos", do Laboratório de Criatividade da Industria Criativa, e participa no grupo "Arte e tecnologia: interfaces híbridas da imagem entre mediações e remediações". Possui experiência na área da educação e das Artes Visuais.

Lattes: http://lattes.cnpq.br/0465460829350695

Orcid: https://orcid.org/0000-0002-4102-3087

ouvirouver Uberlândia v. 16 n. 1 p. 160-173 jan. |jun. 2020 
- RESUMO

O artigo tematiza o passado colonizado e a percepção do Outro nas fronteiras da fotografia contemporânea. Uma vez que, o nascimento da fotografia foi simultâneo ao estabelecimento da antropologia, formatando estereótipos e imaginários sobre a alteridade ao longo do século XIX, e que estão presentes nas representações fotográficas contemporâneas. Assim, questiona-se quais imaginários e estereótipos, criados desde o colonialismo, são colocados em evidência na arte contemporânea, através da análise da produção artística de Julie Moos e Santiago Sierra, que por meio de suas obras fazem novas leituras e deslocamentos dos paradigmas coloniais em relação à alteridade. Projetos artísticos contemporâneos que transgridem os antigos modelos fotográficos herdados do colonialismo.

\section{PALAVRAS-CHAVE}

Arte contemporânea, fotografia, colonialismo, deslocamentos, alteridade.

\section{ABSTRACT}

The article consider the colonized past and the Other on the borders of contemporary photography. The birth of photography was simultaneous to the establishment of anthropology, generating stereotypes and imaginaries about the otherness throughout the nineteenth century, which are present in contemporary photographic representations. Thus, one wonders which imageries and stereotypes created since colonialism are represented in contemporary art through the analysis of the artistic production of Julie Moos and Santiago Sierra, who through their works make new readings and displacements of colonial paradigms in relation to the otherness. Contemporary artistic projects that transgress the old photographic models inherited from colonialism.

\section{KEYWORDS}

Contemporany art, photography, colonialism, displacements, otherness. 


\section{Introdução}

As práticas em antropologia e fotografia foram se sedimentando no contexto histórico colonial (NARANJO, 2006). A partir da descoberta de novos territórios, que seriam classificados e determinados pelos sujeitos europeus colonizadores, emergia a antropologia, a etnografia e a fotografia, enquadradas em um projeto de modernidade. Um colonialismo nascido no interior da Europa, que tem gerado imagens e imaginários sobre o Outro colonial (MIGNOLO, 2000), e que de forma simultânea, também definiram o sujeito colonizador, a imagem do Eu - centro europeu - em relação aos territórios ocupados e sujeitos subalternizados.

Desde a experiência histórica colonial, construída também a partir das representações imagéticas e fotográficas do Outro, fundamentaram-se práticas discursivas, culturais, científicas, e portanto políticas, do poder colonial europeu. A antropologia surge paralela ao colonialismo, ou como afirma categoricamente LéviStrauss (1966), como filha do colonialismo. Em seu processo histórico de formação enquanto pesquisa científica, se interessava em descrever o Outro, criando ou reforçando estereótipos discursivos nascidos das sociedades colonizadoras.

Dessa forma, para Calvo e Oller (2006, p. 207), "quando o índio era fotografado como 'selvagem' era confirmado como 'selvagem'” (tradução nossa) ${ }^{1}$. Assim as teorias antropológicas emergentes, embasaram o controle e o domínio imperialista, que justificariam as intervenções políticas, econômicas, geográficas e científicas da hegemonia europeia nos territórios colonizados.

Nossa investigação nasce a partir da compreensão do Outro colonizado e subalternizado, desde o contexto histórico colonial, dos séculos XV ao XIX, para entender o contexto contemporâneo. Analisamos, a partir das representações fotográficas da alteridade, os imaginários estereotipados sobre o Outro, esse Outro catalogado como migrante, dessemelhante, estranho. Uma relação de categorização que surge a partir do assinalamento e da suspeita: um estranho que existe fora de nossas fronteiras e que classificamos em um determinado grupo, para diferenciá-lo do nós (SIMMEL, 1977).

É, justamente, o sujeito colonial que origina os primeiros debates fotográficos sobre as diferenças, entre o Outro e o nós. Por esse motivo, esta pesquisa é baseada no Outro colonizado, porém, não só nos indivíduos do século $\mathrm{XIX}$, mas aqueles que enfrentam as consequências do colonialismo que se projeta até os dias atuais, permanecendo como esquema de pensamento e estrutura de ação, que legitima as diferenças entre sociedade e sujeitos (RESTREPO; ROJAS, 2010).

A imagem que herdamos do sujeito colonial nos leva a elucidar quais são as fronteiras e deslocamentos do retrato fotográfico - tanto a nível visual como conceitual -, por meio das quais foram lançadas as noções de alteridade e colonialismo, que constantemente se debatem entre objetividade e subjetividade, ficção e documento.

Sendo assim, nossa análise desemboca na fotografia contemporânea, indagando o trabalho de dois artistas, que desde nossa perspectiva, enfatizam os

\footnotetext{
${ }^{1}$ No original: "cuando el indio era fotografiado como 'salvaje' era confirmado como 'salvaje'” (CALVO; OLLER, 2006, p. 207).
}

ouvirouver Uberlândia v. 16 n. 1 p. 160-173 jan. |jun. 2020 
discursos pós-colonialistas: a obra "Domestic", 2001, de Julie Moos e os trabalhos "11 pessoas remuneradas para aprender a dizer uma frase" e "133 pessoas pagas para pintarem o cabelo de loiro", ambas de 2001, de Santiago Sierra.

Julie Moos recorre às noções de diferença e raça como imperativos do passado colonial, das relações sociais deslocadas para atualidade. Enquanto Santiago Sierra toma consciência da narrativa colonizadora, para exercer uma dominação consciente sobre o Outro. Tais artistas produzem deslocamentos nas fronteiras do passado e presente, produzindo obras que se configuram como representações alternativas àquelas esquadrinhadas pela lógica colonial.

Este artigo então, parte da construção dos imaginários colonialistas, para entender quais são os símbolos visuais que herdamos do colonialismo e que se enfrentam com os discursos pós-colonialistas e dos artistas contemporâneos preocupados nestes temas.

\section{Fotografia e antropologia no contexto colonial}

O colonialismo na aurora do século XV e imperialismo do século XIX enquanto processos históricos - formataram, no interior da antropologia e da fotografia, medidas para classificação dos corpos colonizados, baseados nos estudos das ciências naturais. Sendo assim, o caráter do Outro colonial fora avaliado segundo o aspecto visual, físico-corpóreo, para subsidiar noções como raça e evolução (EWING, 1996).

Segundo Serres (2006, p. 31), em um texto originalmente publicado em 1852, a antropologia "determina as condições físicas que separam a humanidade da animalidade, reduzindo a diversidade de raças a sua unidade primitiva" (tradução nossa) $^{2}$. Nesse sentido, o Outro colonial é conformado por meio da racialização comparada ao sujeito ocidental, homem branco europeu, da representação naturalizada - autorreferencial, e supostamente natural - quem designa os limites e as fronteiras em relação ao Outro (MOHANRAM, 1999).

Ainda na década de 1870, uma instituição alemã, chamada Berliner Gesellschaft für Anthropologie ${ }^{3}$, contratou fotógrafos para trabalharem na criação de uma galeria fotográfico- etnológica das diversas raças humanas. Tratava-se de um catálogo que iniciara, segundo a compreensão dos idealizadores, o registro pelas ditas raças superiores, germânicas e teutônicas e decrescia até os aborígenes australianos (EWING, 1996).

Verifica-se que os enunciados científicos do século XIX, acerca do Outro colonial,

[...] embasaram seus estudos na análise mais superficial do homem, em sua morfologia anatômica, a fotografia era o meio de representação visual que oferecia mais precisão e credibilidade (NARANJO, 2006, p. 15) (tradução nossa). ${ }^{4}$

A antropometria colonial, teve uma singular influência das ciências naturais na observação e classificação da alteridade, baseadas no método comparativo da proporção do corpo mediante uma régua colocada ao lado do sujeito ou uma

\footnotetext{
2 No original: "[...] determina las condiciones físicas que separan al hombre de la animalidad, reconduciendo la diversidad de razas a su unidad primitiva" (SERRES, 2006, p. 31).

3 Poderia se traduzir como: Sociedade Berlinesa de Antropologia.
} 
quadrícula no fundo, que permitisse maior objetividade no registro fotográfico (NARANJO, 2006; MONNET; SANTAMARÍA, 2001).

Logo, a fotografia, compreendida como ferramenta acurada e objetiva, cumpriu seu interesse em estudar o Outro: fabricou identidades e imaginários que ilustravam os discursos colonialistas, criando fronteiras que classificavam as sociedades colonizadoras e as colonizadas, calcadas no lluminismo e no projeto de modernidade eurocentrada. Apesar do suposto rigor da visão científica, o sujeito antropológico, tornou-se um objeto, semelhante às plantas e animais, alheio à sua condição de indivíduo. A fotografia era então, percebida como uma técnica de objetividade pura, apesar de projetar os discursos imperialistas sobre as diferenças (MONNET; SANTAMARÍA, 2001).

Tal prisma, nos impele a compreender a hierarquização do Outro, bem como as possibilidades da fotografia para deslocar imaginários, representações e realidades da experiência colonial (DURAND, 1998). Assim, o registro fotográfico do Outro - enquanto objeto -, transita na fronteira simbólica do reconhecimento da diferença e na observação da semelhança, e torna-se reverberação das políticas, culturas e economias coloniais.
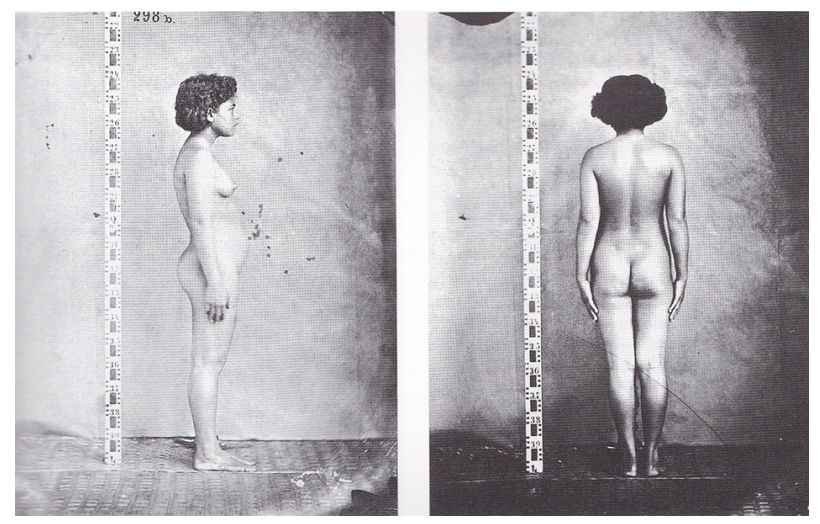

Figura 1. Jovem menina despida (Apia - Upolu) de Johann Stanislaus Kubary, Museu de Etnologia de Hamburgo, Alemanha, 1875.

Diante dos deslocamentos provocados pelo colonialismo, formaram-se movimentos antagônicos produzidos desde a ruptura das fronteiras geográficas, em virtude de processos migratórios globais, e a desconstrução e criação de outras ideologias e representações possíveis. Pode-se pensar nesses movimentos, de maneira geral, como pós-coloniais; dentre os quais figura a arte contemporânea: retomando, intervindo, tensionando, criticando e reinventando as representações visuais e teóricas em torno do passado colonial.

Tais movimentos, visibilizam agentes, comunidades e territórios, com interesse em re-aprender nas fronteiras, dentre os quais destaca-se o decolonialismo latino-americano, que compreende:

Neste espaço fronteiriço de relação e negociação se constroem e emergem novos conhecimentos, sentidos, práticas e ações que

\footnotetext{
4 No original: "[...] basaban sus estudios en el análisis más superficial del hombre, en su morfología anatómica, y que la fotografía era el medio de representación visual que ofrecía más precisión y credibilidad" (NARANJO, 2006, p. 15).
} 
desafiam o poder-saber dominante e começam a infiltrar-se. Por isso, podemos falar de um agir epistêmico, quer dizer, de um interculturalizar epistemológico que constrói novos critérios de razão e verdade (epistemes) e novas condições de saber que não podem ser catalogadas estatisticamente, e cujos impactos e efeitos estão começando a expandir-se mais além da esfera política (WALSH, 2012, p. 52) (tradução nossa). ${ }^{5}$

Imaginários e estereótipos do Outro, do Sul Global - comumente relacionados ao passado, sobre a raça, o exótico, o selvagem, e que forjaram hierarquias sociais -, são encarados contemporaneamente, reconhecendo deslocamentos representacionais e territórios fronteiriços trans e interculturais.

\section{Fissuras e paradoxos do passado colonial na arte e a fotografia contemporânea}

Desde nossa contemporaneidade, torna-se cada vez mais evidente que a conformação do Outro fora atravessado pela matriz de pensamento colonial. A razão e a verdade, hegemônicas no contexto do projeto moderno e colonial passam a ser abordadas nas artes e na fotografia contemporânea, questionando noções como: objetividade, clareza, descrição, fixação e coletividade.

Seguindo pistas de tais deslocamentos, no campo da arte e da fotografia, considera-se razoável pensar no Outro, na perspectiva epistemológica de Deleuze e Guattari (1995): interpretar a alteridade a partir da transformação constante das posições sociais, desde a irredutibilidade do que se constitui múltiplo e móvel, como processo constante de trânsito, manifesto pelo nomadismo.

Dentro deste contexto histórico, nossa pesquisa qualitativa no campo das artes, focaliza em indagar quais imaginários e estereótipos criados sobre o Outro são colocados em evidência na arte contemporânea. Para este fim, abordamos tais representações contemporâneas através da produção artística de Julie Moos e Santiago Sierra. Analisamos o trabalho destes artistas, desde uma perspectiva sociológica: entendendo a materialidade da obra, assim como o contexto socioeconômico, político, e as estratégias discursivas utilizadas por parte dos autores (MARZAL FELICI, 2007).

Para interpretação das obras exercitamos uma ferramenta intercultural (WALSH, 2012), orientada na fronteira do pensar decolonial, uma vez que permite desvelar o passado colonial, devolvendo o olhar para quem olha - questionando quem observa -, percebendo as posições sociais em que o Outro transita, recuperando as trajetórias imaginárias, simbólicas e reais do Outro, bem como, reconhecendo que a observação, produzida pela fotografia, é um processo recíproco, que questiona as posições de objeto-observador: quem observa também é observado.

Nessa direção, as obras e projetos artísticos de Julie Moos e Santiago

\footnotetext{
5 No original: En este espacio fronterizo de relación y negociación se construyen y emergen nuevos conocimientos, sentidos, prácticas y acciones que desafían el poder-saber dominante y empiezan a filtrarse en el. Por eso, podemos hablar de un accionar epistémico, es decir, de un interculturalizar epistemológico que construye nuevos criterios de razón y verdad (epistemes) y nuevas condiciones de saber que no pueden ser catalogadas estáticamente, y cuyos impactos y efectos están empezando a extenderse más allá de la esfera política (WALSH, 2012, p. 52).
} 
Sierra, abordados neste artigo, se relacionam com a temática do passado colonial. A seguir, analisaremos três obras específicas, para perceber a relação entre o nós e o Outro. Como, por meio de suas propostas artísticas, colocam em evidência a suposta documentação da realidade, para passar a ser encarada como um processo de questionamento das representações (BRAVO, 2006). Trabalhos que denotam os paradoxos nas noções de realidade e ficção, apresentando imagens e ações construídas pelo viés documental, mas que recuperam os imaginários e subjetividades herdados do colonialismo.

\subsection{Dualidades em Julie Moos}

Julie Moos nasceu em Ottawa, Canadá, no ano de 1966. Trabalha na área da fotografia e a crítica de arte. Desde os anos noventa, o trabalho de Moos se caracteriza pela realização de séries de retratos: fotografias compostas por dois sujeitos, nos que artista especula visualmente sobre os significados que se deslocam entre as personagens, relacionando-os no sentido de aproximação, distanciamento, contraste e equivalência. Por meio de retratos duplos, Moos compõe a ambiguidade: as personagens se posicionam em frente a câmera, de pé ou sentadas e com poucas expressões faciais ou corporais.

Tais séries de retratos mudam seus significados a partir dos títulos escolhidos por Moos, promovendo ao espectador variadas leituras de sua obra. No trabalho intitulado "Domestic", 2001, apresenta uma série de oito imagens, nas quais incorpora a mesma composição desenvolvida em outras séries fotográficas: imagens de grande formato realizadas em estúdio, com fundo neutro. A utilização da luz é simples, deixando de lado a dramatização nos retratos, sem recorrer a simulações ou ficções: as imagens são diretas e objetivas, os retratados olham diretamente à câmera, ao espectador.

$\mathrm{Na}$ maioria das fotografias apresentadas na série "Domestic", Moos apresenta sujeitos de pele branca ao lado de sujeitos de pele negra. Há uma imagem da série que chama a atenção, intitulada "Julie \& Tatie" (Figura 2), composta de uma mulher caucasiana ao lado de uma mulher de provável ascendência latinoamericana. Recuperando o título da série fotográfica, "Domestic", podemos compreender alguns dos significados deslocados, das relações de trabalho entre os dois sujeitos: "Domestic" poderia ser interpretada como trabalhador doméstico. Assim, visualmente, impele-se a pensar quem trabalha para quem, quem é a chefe e

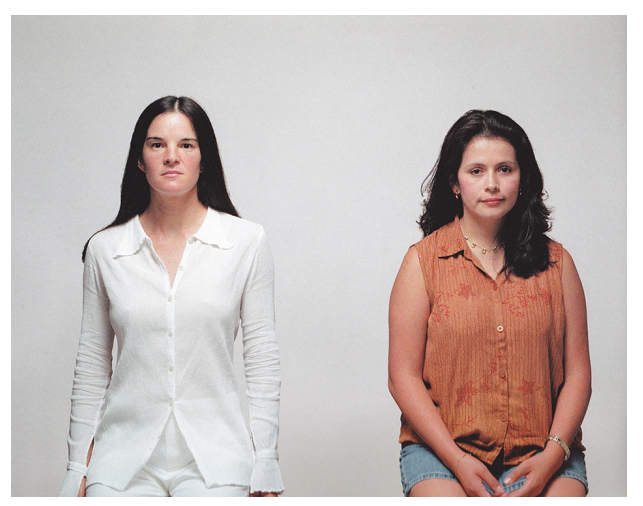
quem é a doméstica. Moos provoca, a partir da observação de sua obra e do que é assumido como narrativa, a deparar-se com nossas próprias representações estereotipadas.

Figura 2. Julie \& Tatie, fotografia, 101,6x132 cm, Julie Moos, 2001. Fonte: http://www.fredericksfreisergallery.com/ 
A artista descontextualiza o local onde fotografa os sujeitos: não temos informações periféricas que nos ajudem a desvelar a relação entre os indivíduos no espaço privado ou de trabalho; mas isso não impede o juízo de valor por parte do espectador. Ao encarar as imagens pretendemos reconhecer o papel de cada um dos fotografados, quem é o criado e quem é o patrão, quem é o proprietário e quem o estrangeiro, porque assumimos que o branco é o nativo e o mestiço ou negro é o imigrante ou ascendente de imigrantes.

Tais imagens são perpetradas por séculos na memória social, ou como afirma Susan Sontag (2003, p. 99-100), na instrução coletiva: "as ideologias criam arquivos de evidência de imagens, imagens representativas, as quais fixam ideias comuns de significações e desencadeiam reflexões e sentimentos previsíveis" (tradução nossa) 6 . Uma memória, que não está relacionada com uma lembrança pessoal, mas com um imaginário coletivo, que é mediado por interesses de nosso ambiente imediato.

Recupera-se imagens do arquivo das representações coloniais, baseadas na racialização, hierarquização e subalternização. As vestimentas das mulheres são outro traço visual distintivo, presumindo que a mulher da direita está vestindo roupas informais, em relação a da esquerda, confirmaria-se o estereótipo de que por isso ela seria a empregada doméstica?

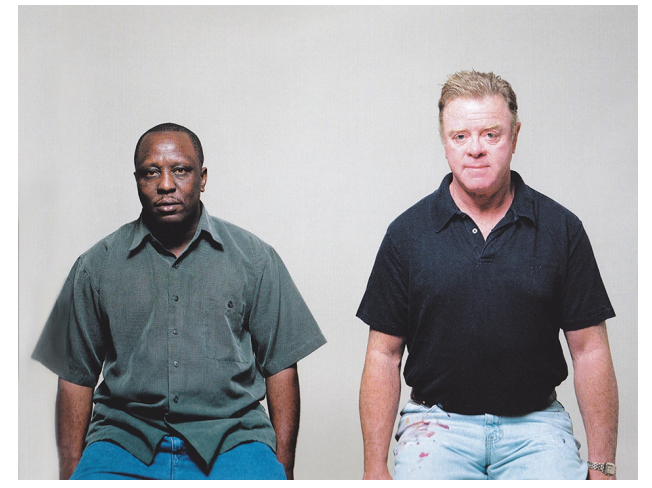

Figura 3. Lawrence \& Dick, fotografia, 101,6×132 cm, Julie Moos, 2001. Fonte: http://www.fredericksfreisergallery.com/

Outra das imagens da série é o retrato de "Lawrence \& Dick" (Figura 3). O homem branco veste calças manchadas de tinta, representando desalinho em relação ao homem negro à sua direita. Porém continuamos com a suspeita de que ele pode ser o empregador. A fotografia apresenta duas pessoas sentadas, sem nenhum tipo de simbolismos ou hierarquias; no entanto nosso arquivo visual e cultural, herdado do colonialismo, antecipa a realidade. Assim, o trabalho de Moos nos desloca diante de suposições e estereótipos que possuímos, e nos impele a reconhecer os mecanismos pelos quais são produzidas tais representações (ODITA, 2002).

Vale mencionar que tais imagens são produzidas em Birmingham, Alabama, nos Estados Unidos da América, um território historicamente marcado por conflitos raciais, em virtude do processo de segregação e discriminação das pessoas negras nos anos de 1960, espaço no qual movimentos antirracistas apoiados por Martin Luther King Jr. desenvolveram-se. Certamente pode-se conjecturar, que nos retratos de Moos, o poder político e econômico da cidade está concentrado em uma parcela

6 No original: "las ideologías crean archivos probatorios de imágenes, imágenes representativas, las cuales compendian ideas comunes de significación y desencadenan reflexiones y sentimientos predecibles" (SONTAG, 2003, p. 99-100). 
da população, das pessoas brancas que atualmente são minoria em dados populacionais.

Os retratos de Moos, sugerem interpretar o Outro na perspectiva intercultural, em consequência da memória coletiva do colonialismo, atravessado pela racialização, segregação e discriminação na intricada rede de poder subalternizante. Moos nos ajuda a reconhecer e desvelar os imaginários visuais produzidos pelo poder colonialista no contexto do século XXI, por meio dos marcadores sociais de raça e classe.

\subsection{O papel do colonizador na obra de Santiago Sierra}

Santiago Sierra nasceu em Madrid, Espanha, no ano de 1966. Seu trabalho focaliza na realização de ações e performances, utilizando a fotografia e o vídeo como ferramentas de registro. A partir de seu posicionamento político e estético discute acerca do sistema constituído pelo discurso colonialista e das relações no interior das estruturas hierárquicas e de poder. Sierra, segundo o teórico Iván Mejía, "brinca com os estereótipos e figuras do colonizado e do colonizador. Ele se apropria do papel do colonizador, do explorador, do usurpador, do punidor, do patrão. O Outro é seu oposto imediato: o explorado, usurpado, o punido, o escravo" (MEJÍA, 2010).

Analisamos neste artigo, duas ações realizadas pelo artista em 2001: "11 pessoas remuneradas para aprender a dizer uma frase" e "133 pessoas pagas para pintarem o cabelo de loiro". A primeira performance foi realizada em Chiapas no México, na qual contratou mulheres, falantes da língua indígena tzotzil, que aprendiam a dizer a seguinte frase em espanhol: Estoy siendo remunerado para decir algo cuyo significado ignoro ${ }^{7}$. Um professor lhes ensinava a frase pela repetição insistente da mesma.

A performance foi registrada em vídeo e fotografia (Figura 4). Trata-se de uma composição em plano geral, preto e branco, retratando o grupo de mulheres indígenas, paramentadas com as roupas tradicionais de sua região, sentadas no que parece ser os bancos de uma igreja ou de uma escola. O olhar das mulheres está direcionado à esquerda, lugar no qual está o professor de espanhol contratado.
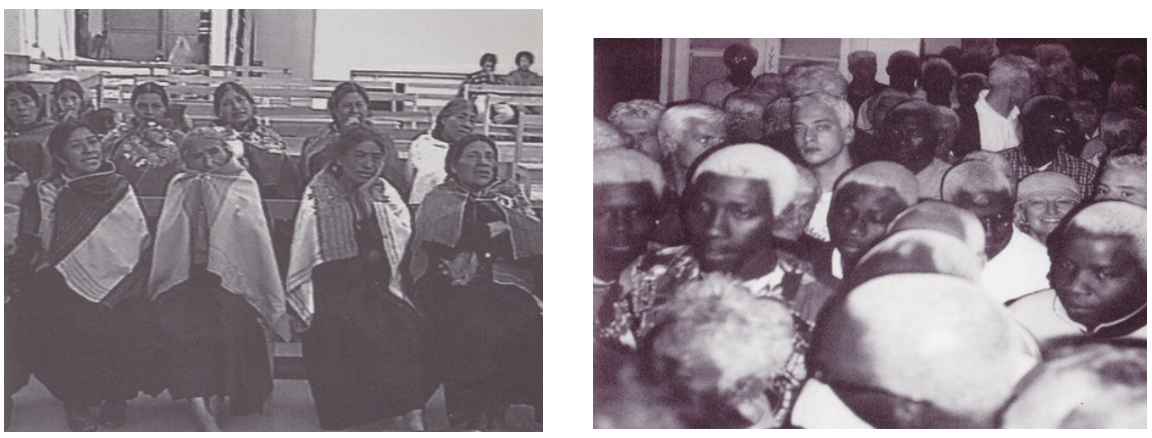

Figura 4. 11 pessoas remuneradas para aprender a dizer uma frase. Registro fotográfico da

\footnotetext{
$\overline{7}$ Tradução nossa: Estou sendo remunerado para dizer algo que não sei o significado
} 
performance na Casa da Cultura de Zinacantán. México. Março 2001. Onze mulheres indígenas tzotziles, sem nenhum conhecimento da língua espanhola, foram reunidas em uma sala para ensiná-las a dizer uma frase em espanhol. A frase era: "Estou sendo paga para dizer algo cujo significado eu ignoro". Elas cobraram \$2 por pessoa (tradução nossa). ${ }^{8}$ Fotografia de Santiago Sierra, 2001. Fonte: https://www.santiago-sierra.com

Figura 5. 133 pessoas pagas para pintarem o cabelo de loiro. Arsenal. Registro fotográfico da performance em Veneza, Itália. Junho 2001. Um grande número de imigrantes de diversas origens, trabalha como vendedores ambulantes ilegais na cidade de Veneza. Italianos, senegaleses, bengalis, chineses e até italianos do sul. Eles foram convocados para que concordassem para pintarem o cabelo de loiro por 120.000 liras, uns $\$ 60$, sendo a única condição ter cabelos escuros. A operação foi realizada em massa em uma sala fechada do Arsenal, durante a abertura da Bienal de Veneza daquele ano. Embora se esperasse pintar 200 pessoas, foram só 133 porque a chegada de imigrantes ocorreu de maneira escalonada, sem poder determinar com precisão quantas pessoas já estavam na sala. Decidiu-se fechar a entrada, calculando aproximadamente o número de pessoas. Isso causou inúmeros problemas a porta devido ao fluxo incessante de pessoas que ainda queriam entrar (tradução nossa $)^{9}$. Fotografia de Santiago Sierra, 2001. Fonte: https://www.santiago-sierra.com

Por meio de esta obra, pode-se recuperar a temática da imposição, historicamente construída, de línguas estrangeiras nos territórios colonizados. O exercício de repetir frase para doutrinar culturas, representa o domínio hierárquico de uma cultura sobre a outra, colocando em evidência a exclusão dos âmbitos do saber e do poder dos povos colonizados (MARTíNEZ, 2003). Uma performance realizada, não por acaso, em Chiapas, que mantém uma relação contraditória de interdependência com o estado mexicano, ecoando situações de dominação cultural e linguística, mas também da precariedade econômica, laboral e de proteção dos povos indígenas que habitam na região (DEL RíO, 2002).

A segunda performance que analisamos em nossa pesquisa se intitula "133 pessoas pagas para pintarem o cabelo de loiro". Foi realizada durante a inauguração da Bienal de Veneza em 2001, e participaram migrantes ilegais remunerados para terem os cabelos pintados de loiro. A fotografia que reproduzimos registra a performance (Figura 5). É uma imagem em preto e branco, na qual pode-se observar o contraste dos cabelos já pintados de loiro. A maior parte das pessoas que são registradas na imagem, são negras, embora seja difícil perceber a totalidade de gêneros, etnias ou origens das pessoas que participaram da performance.

Podemos analisar a obra de Sierra desde duas perspectivas diferentes: por

\footnotetext{
8 No original: "11 personas remuneradas para aprender una frase. Casa de la Cultura de Zinacantán. Zinacantán, México. Marzo de 2001. Once mujeres indias tzotziles, sin conocimiento alguno de la lengua española, fueron reunidas en una sala para enseñarles a decir una frase en español. La frase era: 'Estoy siendo remunerado para decir algo cuyo significado ignoro'. Cobraron 2\$ por persona” (SANTIAGO SIERRA,2001).

9 No original: "133 personas remuneradas para teñir su pelo de rubio. Arsenal. Venecia, Italia. Junio de 2001. En la ciudad de Venecia trabajan como vendedores ambulantes ilegales una gran cantidad de inmigrantes de orígenes dispares. Senegaleses, bengalíes, chinos e incluso italianos del sur. Se les requirió para que consintiesen en ser teñidos de rubio por 120.000 liras, unos 60\$, siendo la única condición tener el cabello oscuro. La operación se realizó en masa en una sala cerrada del Arsenal, durante la inauguración de la Bienal de Venecia de ese año. A pesar de que se preveía teñir a 200 personas, solo fueron 133 debido a que la llegada de inmigrantes se produjo de forma escalonada, sin que se pudiese establecer con precisión cuántas personas se encontraban ya dentro de la sala. Se decidió entonces cortar el ingreso calculando a ojo. Esto causó numerosos problemas en la puerta por el incesante flujo de personas que aún pretendían entrar" (SANTIAGO SIERRA, 2001).
} 
uma parte lembra a classificação das raças segundo a antropometria e os aspectos físicos, desenvolvidos pelos fotógrafos-antropólogos coloniais. E por outra parte, pintar o cabelo de loiro representa a homogeneização e subalternização dos sujeitos, com interesse na eliminação das diferenças do Outro colonial. Porém, na contemporaneidade, tal ação pode-se constituir como estratégia contrária à mimetização, uma vez que são imigrantes ilegais e estão na mira da polícia, sendo que pintar o seu cabelo, é um exercício de assinalamento que facilitaria a deportação xenófoba (MEJÍA, 2010).

Estas imagens, bem como todas as que documentam o trabalho de Sierra são elaboradas em preto e branco, aprofundando no carácter abertamente documental de sua obra, sobre a qualidade estética da mesma. Sem nenhum juízo de valor, os títulos e legendas descritivas das imagens, apresentam a postura e precisão dos eventos a serem observados pelo público.

$\mathrm{O}$ artista se reconhece como um feitor dos acontecimentos, num mundo onde convivemos com as repercussões das ideologias e imaginários colonialistas:

(...) utilizei estrategicamente meu status de espanhol no México e na América Latina, onde é muito fácil identificar meu sotaque com a exploração, simplesmente por razões históricas. Tiro vantagem para destacar questões como os privilégios do branco, a cor do empregador, a diferença com a cor do empregado (JIMÉNEZ, 2005). ${ }^{10}$

Ao pagar os participantes para que constituam seu trabalho, Sierra exercita a hierarquia e imposição causando desconforto ao espectador diante de tais práticas, forçando também as fronteiras éticas (WILLIAMS, 2003). A obra de Sierra é uma réplica dos mecanismos de poder da sociedade: o artista não oculta as condições de negociação em sua obra, revela uma estrutura social, política, económica e cultural encardida, que tem se preservado ao longo de séculos e que manifesta a atemporalidade de sua obra.

\section{Considerações finais}

As obras de Julie Moos e Santiago Sierra, se aproximam de diferentes formas do Outro colonial na contemporaneidade, buscam representações das ideologias coloniais, bem como propõem, a partir da interculturalidade, um posicionamento em relação com o Outro.

Verifica-se que a fotografia e a antropologia serviram a ordem,

[...] tipicamente moderna, a substância da política moderna, do intelecto moderno, da vida moderna, é o esforço para exterminar a ambivalência: um esforço para definir com precisão - e suprimir ou eliminar tudo que não poderia ser ou não fosse precisamente definido (BAUMAN, 2012, p. 13).

Nesse sentido, a transformação dos paradigmas científicos e socioculturais possibilitaram horizontalizar a construção do conhecimento. Assim o Outro, convertido em objeto segundo o pensamento colonialista, desloca-se para a

\footnotetext{
${ }^{10}$ No original: “ (...) he utilizado estratégicamente mi condición de español en México y en Latinoamérica donde es muy fácil identificar mi acento con la explotación simplemente por razones históricas. Lo utilizo para poner en evidencia cuestiones como el privilegio del blanco, el color del empleador, la diferencia o con el color del empleado" (JIMÉNEZ, 2005).
} 
semântica do nós “hoje 'nós' e 'eles' se observam: a comunicação visual se torna instrumento para um conhecimento recíproco" (CALVO; OLLER, 2006, p. 206) (tradução nossa) ${ }^{11}$.

O desvelar dos vestígios da colonialidade contemporânea nos projetos de Moos e Sierra, é alcançado tanto pela adaptação dos recursos visuais de fotografias no contexto contemporâneo, quanto pelo reconhecimento do Outro desde a experiência da diáspora e da migração. Assim como afirma Canclini (1999), a posição do artista figura no entremeio e no trânsito, tal modo que os limites e as fronteiras, mais que rupturas se convertem em espaços que permitem a potência da criação em arte.

A partir destes trabalhos artísticos, surge o processo de fabricação de lateralidades e fronteiras que dialogam com o pós-colonialismo, com a necessidade do reconhecimento das semelhanças e as diferenças. A alteridade, justamente, não nega a diferença, mas reconhece que ela constitui um nós, uma ética de comportamento que respeita a subjetividade e a pluralidade de cada indivíduo e o contexto em que esse encontro acontece.

A ambivalência dicotômica que cria o Outro "[...] é um exercício de poder e ao mesmo tempo uma dissimulação" (BAUMAN, 2012, p. 21). Desde a fotografia e a arte contemporânea, o Outro existe, a partir do encontro entre o simbólico e o imaginário, sempre múltiplo e fragmentado, em constante deslocamento.

\section{REFERÊNCIAS}

BAUMAN, Zygmunt. Modernidade e ambivalência. Rio de Janeiro: Zahar, 2012.

BRAVO, Laura. Ficciones Certificadas. Invención y apariencia en la creación fotográfica

[1975-2000]. Madrid: Editorial Metáforas del Movimiento Moderno, 2006.

CALVO, Luis Calvo; OLLER, Josep Mañà. El valor antropológico de la imagen. ¿hacia el "homo photographicus"? In: NARANJO, Juan (org.). Fotografía, Antropología y Colonialismo (1845-2006). Barcelona: Gustavo Gili, 2006. p. 205-212.

DELEUZE, Gilles; GUATTARI, Felix. Mil Platôs. Capitalismo e Esquizofrenia. Rio de Janeiro: Editora 34, 1995.

DURAND, Régis. El tiempo de la imagen. Ensayo sobre las condiciones de una historia de las formas fotográficas. Salamanca: Universidad de Salamanca, 1998.

EWING, William. El Cuerpo: fotografías de la configuración humana. Madrid: Ediciones Siruela, 1996.

JIMENÉZ, Carlos. México es como una ciudad-tumor: entrevista con Santiago Sierra. EI País. Espanha, fev. 2005. Disponível em: <https://elpais.com/diario/2005/02/05/babelia/1107563956_850215.html>.

\footnotetext{
$\overline{11}$ No original: "hoy 'nosotros' y 'ellos' nos observamos mutuamente: la comunicación visual deviene, ahora,
} instrumento para un conocimiento recíproco” (CALVO; OLLER, 2006, p. 206). 
Acesso em: 20 set. 2019.

MARTÍNEZ, Rosa. Santiago Sierra. Ministerio de Asuntos Exteriores. Dirección General de Relaciones Culturales y Científicas: Turner, 2003. 271 p. Catálogo de exposição (15 jun. - 2 nov. 2003), Pabellón de España. 50a Bienal de Venecia, Venecia.

MARZAL FELICI, Javier. Cómo se lee una fotografía. Interpretaciones de la Mirada. Madrid: Ediciones Cátedra, 2007.

MEJÍA, Ivan. Escritos sobre cultura y arte contemporáneo. México: Pluma Roja Editorial, 2010.

MIGNOLO, Walter. Local Histories/Global Designs: Coloniality, Subaltern Knowledges and Border Thinking. New Jersey: Princeton University Press, 2000.

MOHANRAM, Radhika. Black body: women, colonialism, and space. Minneapolis: University of Minnesota Press, 1999.

MONNET, Nadja; SANTAMARÍA, Enrique. Fotografía y alteridades. A vueltas con los usos de la fotografía y el sentido de los otros. Quaderns-e, n. 16, 2001, p 1-15.

NARANJO, Juan. Medir, observar, repensar. In: NARANJO, Juan (org.). Fotografía, Antropología y Colonialismo (1845-2006). Barcelona: Gustavo Gili, 2006. p. 11-23.

ODITA, Donald. Julie Moos. Flash Art , XLV, n. 229, 2002.

RESTREPO, Eduardo; ROJAS, Alex. Inflexión decolonial: fuentes, conceptos y cuestionamientos. Popayán: Universidad del Cauca, 2010.

SIERRA, Santiago. Site do artista. Disponível em: <http://www.santiago-sierra.com>. Acesso em: 09 de out. de 2019.

SIMMEL, Georg. Sociologia: estudios sobre las formas de socialización. José Pérez Bances. Madrid: Alianza Editorial, 1977.

SERRES, Etienne. Fotografía Antropológica In: NARANJO, Juan (org.). Fotografía, Antropología y Colonialismo (1845-2006). Barcelona: Gustavo Gili, 2006. p. 31-32.

SONTAG, Susan. Ante el dolor de los demás. Madrid: Santillana Ediciones Generales, 2003.

U.S. CENSUS BUREAU. 2010 Census Interactive Population Search. Disponível em: <http://2010.census.gov/2010census/popmap/ipmtext.php?fl=01>. Acesso em: 09 de out. de 2019.

WALSH, Catherine. Interculturalidad crítica y (de)colonialidad: Ensayos desde Abya Yala. Quito: Ediciones Abya-Yala, 2012.

WILLIAMS, Gilda (org.). Cream 3. Contemporary Art in Culture. 10 Curators, 10 Writers, 
100 Artists. London, New York: Phaidon, 2003.

Recebido em 17/10/2019 - Aprovado em 01/13/2020

Como citar:

Rueda, L. R., Souza, G., \& Becker, A. (2020). Deslocamentos na percepção do Outro colonial desde a arte contemporânea. OuvirOUver, 16(1), 160-173. https://doi.org/10.14393/OUV26-v16n1a2020-51086

(c) (7) \& A revista ouvirOUver está licenciada com uma Licença Creative BY NC Commons Atribuição-NãoComercial 4.0 Internacional. 